paper by strongly supporting Jackson's excellent paper $^{2}$ in its plea that the family doctor in training should be involved in the care of paediatric abdominal emergencies in hospital. This suggestion still needs practical support.

Peter F JoNes

Aberdeen 1 Winsey, H S, and Jones, P F, British Medical fournal,

2 Jackson, R H, British Medical fournal, 1963, 2, 277.

\section{Prognostic value of early features in rheumatoid disease}

SIR,-I shall be grateful if you will kindly allow me on behalf of my colleagues to apologise to Professor J Wawrzyńska-Pagowska and colleagues (9 October, $p$ 876) for misquoting their article. ${ }^{1}$ In fact they studied exactly the same number of patients as we did although their patients were pre-erosive. We are pleased that our own results ${ }^{2}$ are in broad agreement with theirs and look forward to reading the report on their 10-year follow-up.

MARY CORBETT Middlesex Hospital,

London W 1

' Wawrzyŕska-Pagowska, J, et al, Acta Rheumatologica Fleming, A, et al, British Medical fournal, 1976, 1 1243.

\section{Syphilis presenting as hair loss}

SIR,-I was most interested to read of the two cases reported by Dr C Kennedy (9 October, p 854). I saw a similar case about 25 years ago and do not believe that I have seen another since. My patient was a young man with patchy baldness who brought a letter from his doctor asking if there was any effective treatment for alopecia areata. He was, it stated, otherwise healthy but had visited the surgery twice in the previous few months, once for a "labial herpes" and the second time for a mild pyrexia. This was treated with sulphonamides but they were stopped when he broke out in a rash. It all fitted very nicely.

H T H WILSON

London W 1

\section{Oxytocin and neonatal jaundice}

SIR,-A recent short report on the role of oxytocin in producing neonatal jaundice (4 September, p 564) concluded that jaundice associated with its use was the result of the lower gestational age of babies produced rather than a toxic effect of oxytocin itself. When considering "lower gestational age" as the cause of neonatal jaundice in these circumstan- ces the tendency is to think of a gestational age of less than 37 weeks.

In a recent retrospective but controlled study babies who became markedly jaundiced (bilirubin $\geqslant 15 \mathrm{mg} / 100 \mathrm{ml}(256 \mu \mathrm{mol} / \mathrm{l})$ were matched for gestational age with babies who were not jaundiced. ${ }^{1}$ Significantly more of the jaundiced babies had been born after oxytocin was used to induce labour, while the percentage who had had oxytocin commenced during labour was almost the same in both jaundiced and non-jaundiced groups.

As the mean gestational ages of both groups were not significantly different and most were at term, that is, 37-42 weeks (see table), it seems likely that the spontaneous onset of labour was being anticipated by perhaps just a few days and that this led to an increase in the incidence of severe neonatal jaundice. The findings support the idea that there is a failure to "prime" fetal enzyme systems if labour is induced early. ${ }^{2}$

D G SIMS

${ }^{1}$ Sims, D G, and Neligan, G A, British fournal of
Obstetrics and Gynaecology, 1975, 82, 863.
${ }^{2}$ Davies, D P, et al, British Medical fournal, 1973, 3 Davies,
476.

\section{Thyrotoxicosis induced by iodine in food}

SIR,-I thank Drs J C Stewart and G I Vidor for their kind comment (18 September, p 701) on my letter about thyrotoxicosis induced by iodine in food (24 April, p 1016). I agree with them on all the general principles.

There must, of course, be some difference between those goitre patients who become thyrotoxic after iodine repletion and those who do not. The latter may obviously have an increase in thyroid hormone production within so-called normal limits, whereas the former proceed to clinical thyrotoxicosis. If the thyroid-pituitary axis were always to respond in the way Drs Stewart and Vidor suggest, then few if any of these patients would become thyrotoxic at all.

Thyroid nodules may, as Drs Stewart and Vidor so clearly point out, often be the result of iodine depletion, such as has been seen also in this country.

Patients with large iodine-deficient goitres have athyroid hormone production reserve so large that adjustment to low TSH stimulation must certainly take some time after iodine repletion and thus make thyrotoxicosis more probable than in patients with small goitres. The same may be true when iodine depletion has prevailed for a long time, which may explain the higher incidence with age of thyrotoxicosis after iodine repletion which was observed by Drs Stewart and Vidor.

Aland Central Hospital,

Mariehamn
Finland

\begin{tabular}{|c|c|c|c|c|c|c|}
\hline & \multicolumn{2}{|c|}{ Overall matching } & \multicolumn{2}{|c|}{ Oxytocin induction } & \multicolumn{2}{|c|}{ Oxytocin to expedite } \\
\hline & $\begin{array}{c}\text { Case } \\
\text { numbers }\end{array}$ & $\begin{array}{c}\text { Mean age } \\
\text { (weeks) } \\
\pm \text { SD } \\
\text { Range } \\
\text { (weeks) }\end{array}$ & $\begin{array}{c}\text { Case } \\
\text { numbers }\end{array}$ & $\begin{array}{c}\text { Mean age } \\
\text { (weeks) } \\
\pm \text { SD } \\
\text { Range } \\
\text { (weeks) }\end{array}$ & $\begin{array}{c}\text { Case } \\
\text { numbers }\end{array}$ & $\begin{array}{c}\text { Mean age } \\
\text { (weeks) } \\
\pm \text { SD } \\
\text { Range } \\
\text { (weeks) }\end{array}$ \\
\hline $\begin{array}{l}\text { Jaundice } \\
\text { Control } \\
\text { Significance }\end{array}$ & $\begin{array}{l}46 \\
92\end{array}$ & $\begin{array}{c}38 \cdot 8 \pm 1 \cdot 6 \\
34-41 \\
39 \cdot 1 \pm 1 \cdot 5 \\
34-41 \\
\mathrm{P}<0.5 \mathrm{NS}\end{array}$ & $\begin{array}{l}24 \\
26\end{array}$ & $\begin{array}{c}39 \cdot 4+1 \cdot 6 \\
35-41 \\
39 \cdot 9 \pm 1 \cdot 2 \\
36-41 \\
P<0.3 \mathrm{NS}\end{array}$ & 12 & $\begin{array}{c}38 \cdot 4 \pm 1 \cdot 3 \\
37-40 \\
38 \cdot 8 \pm 1 \cdot 9 \\
36-41 \\
\mathrm{P}<0.7 \mathrm{NS}\end{array}$ \\
\hline
\end{tabular}

\section{Postoperative pain}

SIR,- The painful necessity of trying unaided to sit up from lying down in the first few days after abdominal surgery was dreaded by myself like most patients. I found that this could be overcome as follows. Intelligent patients can be taught to concentrate on the use of an alternative muscle group instead of the abdominal muscles. The patient draws up one knee far enough to clasp both hands together behind the knee with the arms straight, while relaxed and leaning back to allow the body weight to be lifted at the next phase. The other foot remaining under the weight of the bedclothes, etc, is sufficient to balance the body weight as the bent knee is quietly straightened with only one thought in mind-to bring the other foot down alongside its opposite number.

The pull of the hamstrings on to the clasped hands easily raises the relaxed trunk into the upright position, painlessly, provided the patient makes no attempt to tighten the abdominal muscles and concentrates on putting the raised foot down to the bottom of the bed. (For the mechanically minded, the iliopsoas group takes the place of the abdominal muscles in lifting the trunk in this manoeuvre in opposition to the hamstrings.)

JOHN B TRACEY

Pinhoe, Exeter

\section{A medical saga}

SIR,-The history sympathetically outlined by Sir Harold Himsworth (2 October, p 792) made compelling reading to those who knew of a less lucky saga. Brief details of a more poignant story may therefore be of interest.

A Scotsman who had spent his childhood in South Africa went up to Cambridge in 1913 . He had a car accident while still an undergraduate, and this left him with an arthrodesed left hip. After graduating he went to the United States for a year on a travelling scholarship. While there he married an American, whose mother was one of the earlier women doctors. He then joined the RAMC as a medical entomologist, and worked in this country and in East Africa. After the 1914-8 war he was appointed to the Burroughs Wellcome Research Bureau and visited Mauritius in 1922 . He wrote articles about the life cycle of mosquitoes and published his malarial surveys. He became a DSc and invented an electronic rectifier. A firm making accumulators purloined his invention, and after a law-suit he received only nominal damages. He had hoped to obtain an FRS, but instead he developed Addison's disease in 1932 at the age of 43 . He became weaker, more pigmented, and began vomiting, despite treatment with sodium chloride. He died in January 1933, just before DOCA therapy was available. His wife died, seven years later, from lung fibrosis caused by postoperative $x$-ray treatment for a mammary carcinoma. His father, sister, and one brother died from alimentary neoplasms, and his remaining brother developed insulin-diabetes six years ago. His older son had typhoid fever in transit to Mauritius and later pneumonia before Prontosil was introduced. $\mathrm{He}$ has also had coeliac disease for the last 55 years. ${ }^{1}$

Some questions are decided by either hereditary or environmental factors. Tuberculosis and sarcoidosis occur together in some families. The father of the first reported case of sarcoid Addison's disease had, for instance, died of pulmonary tuberculosis, ${ }^{2}$ and three cases of this syndrome have since been recorded. ${ }^{3-5}$ This Scotsman's accident possibly reactivated a tuberculous focus in his hip joint. $\mathrm{He}$ had no evidence later of tuberculosis, 